\title{
Hashtag war: 2019 Presidential election rhetoric in Indonesia
}

\author{
Avin Fadilla Helmi ${ }^{1}$, Mardhani Riasetiawan ${ }^{2}$, Acintya Ratna Priwati ${ }^{3}$, Itsna Mawaddata \\ Rahma $^{4}$, Arlianto ${ }^{5}$, Ramadhan Dwi Marvianto ${ }^{6}$, Rinanda Rizky Amalia Shaleha ${ }^{7}$ \\ 1,3,4,5,6,7 Faculty of Psychology, Universitas Gadjah Mada, Indonesia \\ ${ }^{2}$ Faculty of Mathematics and Natural Science, Universitas Gadjah Mada, Indonesia \\ ${ }^{5}$ Faculty of Psychology, Universitas Wisnuwardhana, Indonesia \\ ${ }^{7}$ Department of Psychology, Universitas Pendidikan Indonesia, Indonesia \\ ${ }^{1}$ avinpsi@ugm.ac.id., ${ }^{2}$ mardhani@ugm.ac.id., ${ }^{3}$ acintya.ratna.p@ugm.ac.id., \\ 4itsna.mawadatta.r@mail.ugm.ac.id., 5arlianto@mail.ugm.ac.id., rramadhan.dwi.m@mail.ugm.ac.id., \\ 7rinandarizkyas@upi.edu.
}

ARTICLE INFO

Article history

Received 22 June 2020

Revised 30 July 2020

Accepted 31 July 2020

Keywords

general election

hashtag

political rhetoric

social media

twitter

\begin{abstract}
Twitter as a social media has become increasingly used, including by its use by each Presidential candidate's stronghold to launch a campaign to influence prospective voters' electoral decisions in the 2019 Presidential Election in Indonesia. One strategy used in such a campaign on Twitter was by disseminating hashtags that were expected to become trending topics on Twitter. The dissemination of these hashtags aimed to build political rhetoric that can influence prospective voters' electoral decisions. Thus, this study sought to explore the patterns of hashtags disseminated by each candidate's stronghold to build political rhetoric and find out public sentiments in the posted Twitter contents. The number of tweets with \#Jokowi2Periode and \#2019GantiPresiden hashtags during the period of the 2019 Indonesian presidential and vice-presidential debates that were successfully downloaded using MAXQDA 18.1.1 software was 92,276 . The research findings revealed that the distribution pattern of the \#Jokowi2Periode hashtag tended to be more scattered (decentralized) by relying on the actor's presentation and the actor's speed in responding to tweets. In contrast, the spread of the \#2019GantiPresiden hashtag was more centralized by relying on communication channels on Twitter. These two distribution patterns are discussed with the perspective of cyber psychology, through cuesfiltered-in and cues-filtered-out theories.
\end{abstract}

\section{Introduction}

Twitter as a social media has been tested as a means of building political rhetoric as seen in its use by President Barack Obama, for example, to predict the contestation of the 2008 and 2012 Presidential Elections in $76 \%$ of the states of the United States with a fairly high degree of accuracy (Johnson, 2012). In other words, Twitter can be used by presidential candidates to campaign for their visions and missions (Enli, 2017); even when the accuracy of the online disseminated message is unclear (Lachlan, Westerman, \& Spence, 2010; Vlatković, 2018). However, some other experts do not trust social media as a reference to predict future events, because it is a virtual space dominated by computer users (Jahanbakhsh, King, \& Shoja, 2012; Papacharissi, 2002). This debate suggests the importance of doing further research on how social media, Twitter, in particular, can be used as an accurate source in various contexts, especially in Indonesia as an archipelagic country with diverse ethnic groups. 
During the 2019 Presidential Election in Indonesia, Twitter was used as a medium for political marketing through hashtag posts from both candidates' supporters. During that contestation, two prominent hashtags became trending topics on Twitter, which were \#2019GantiPresiden and \#Jokowi2Periode (Aji, 2018; Hakim, 2018). The \#2019GantiPresiden hashtag was declared by politician Mardani Ali Sera, a supporter of presidential candidate number 02 (Kuwado, 2018; Triyoga \& Nugraha, 2018), to provide political education to prospective voters (Aji, 2018; Naren, 2018). The \#2019GantiPresiden hashtag was the antithesis of the political marketing movement of presidential candidate 01 's supporters on Twitter with their \#Jokowi2Periode hashtag (Aji, 2018).

This hashtag war heated up on Twitter's timeline from before the Presidential election process to the actual voting process. In the process of contestation, debates between presidential candidates were held four times and broadcasted on national television. During the first presidential debate process, Twitter's timeline was filled with 1.3 million posts surrounding the presidential election. A week after the first debate, the Indonesian people still pitted each other's arguments to win their respective strongholds' hashtags (Listiyani, 2019). As many as 20.9 million of 192 million registered voters in the permanent voter list in Indonesia were active Twitter users (Makki, 2018). This data means that around $10 \%$ of voters were potentially exposed to information about political campaigns rolling out on Twitter's timeline.

Twitter hashtags used in the presidential campaign on social media were more indicative of engagement between Presidential candidates and their prospective, compared to posts of candidates' posters (Housley et al., 2018; Khoja-Moolji, 2015). Besides their ability to establish closeness, hashtags on Twitter also serve to build political rhetoric in a presidential election (N. Pang \& Law, 2017). Rhetoric is the study of oratory or speech art (Atkins, Finlayson, J, \& Turnbull, 2014; Burke, 1969). Language skills and proficiency are used to convey thoughts and ideas through speeches to certain mass groups to achieve specific goals. Rhetoric, as a form of persuasive language or writing, aims to control reality to influence certain groups of people. Rhetoric is systematically and intentionally made from effective emotion expressions and symbolic thoughts, which is to achieve the purpose of using symbols in persuasion (Herrick, 2017).

Besides being seen positively, rhetoric is also seen as negative because it is also used for propaganda, manipulating, and persuading with sweet words (Kennedy, 1991), which is commonly called a negative campaign. A negative campaign can be an effective strategy in political marketing because of its ability to mobilize partisan voters to support the attacker (Ansolabehere \& Iyengar, 1995). Furthermore, a negative campaign is driven by media logic and very conflictual; therefore, much more likely to get attention than positive campaigning (Ridout \& Smith, 2008).

In the world of politics, negative campaigns are legal and commonplace. Negative campaigns are considered effective in attracting the sympathy of prospective voters, mainly if they are targeted at potential voters who have an ideological similarity with the party that launched it (Curini \& Martelli, 2010). Convincing the electorate and maximizing their number of votes is the main goal for political parties during the campaign period (Esser \& Strömbäck, 2012). On the other hand, negative campaigns are not without risk in that even an incumbent candidate's good image may decline when the distorted news is spread in the media (Fridkin \& Kenney, 2011). Negative campaigns can damage, mislead, and confuse the judgment of citizens against nominated candidates. Another more dangerous impact is that negative campaigns can reduce voter participation, even that of the party's loyal voters of the proposed candidates (Franz, Freedman, Goldstein, \& Ridout, 2008).

In reality, one of the social media, Twitter, was used by both presidential candidate pairs to build political rhetoric in the 2019 Presidential Elections in Indonesia to repeat earlier successes such as the Presidential Elections in the United States and several other countries. Therefore, this present study aimed to explore the hashtag distribution patterns that built 
political rhetoric on Twitter as the social media and find out public sentiments in Twitter contents.

From the perspective of cyber psychology, campaigns through Twitter can be explained through the computer-mediated communication (CMC) theory. There are two major groups of CMC theories, namely cues-filtered-in theories and cues-filtered-out theories (Liang \& Walther, 2015). Cues-filtered-in theories emphasize the system or the communication channel, which is focused more on the capacity of the system to convey cues in the communication process and their effects on the communication or interaction process. Cuesfiltered-out theories emphasize the individuals as actors who carry out the process of communication or interaction (Liang \& Walther, 2015).

Social presence theory is a theory that first used a cues-filtered-out approach. This theory states that there are several types of communication systems, each of which is different in the availability of signaling systems. Reduced cues have to do with the decreased social presence among communicators. Limitations in the signaling system have an impact on the level of social information that can be conveyed by a system so that characteristics, personalities, and warm interpersonal relations processes cannot be effectively interchanged without nonverbal cues (Liang \& Walther, 2015). These limitations, due to the lack of nonverbal cues that may reduce group cohesiveness, need another explanation, in this case, it could be explained with the Social Identity Model of Deindividuation Effects (SIDE).

The Social Identity Model of Deindividuation Effects belongs to the cues-filtered-in theories group (Lea \& Spears, 1992). This theory describes the transmission of interpersonal information online is limited by the absence of non-verbal cues. SIDE offers visual anonymity and social identification as the base of an online communication mechanism. Visual anonymity was a condition when text-based communication was applied by the communicators; therefore, no visual information between people involved in the communication. In such a circumstance, the communicators become deindividualized and will identify themselves with a social group that emerges, and may behave following that social group.

In essence, SIDE explains the visual anonymity condition in CMC that makes the individuals involved in the interaction experience deindividuation and identify themselves with a certain group's identity. In such a situation, they will usually try to identify themselves with the group that stands out during the communication or interaction process in the CMC. In the 2019 Presidential Election in Indonesia, polarizations occurred among the two supporter strongholds, the endorsers of \#Jokowi2Periode hashtag vs. that of \#2019GantiPresiden hashtag. A polarization will likely result in in group favoritism. Therefore, this study aimed to find out whether the campaign strategies developed by each candidate in the presidential election campaign that relied on the Twitter platform could be explained with cues-filtered-in theories or cues-filtered-out theories.

\section{Method}

\section{Data Collection Preparation}

Like other social media data, Twitter data can be categorized as big data (Weller, Bruns, Burgess, Mahrt, \& Puschmann, 2014). Given a large amount of potential data available on Twitter, data in the form of tweets were collected during the periods before, during, and after the four Presidential debates. Then, the data were filtered based on the tweet contents that used \#Jokowi2periode and \#2019GantiPresiden hashtags and contained opinions or responses to the debate process (Zappavigna, 2011).

To map conversations that occur on Twitter, one of the commonly used methods is sentiment analysis. This analysis is carried out to reveal opinions about a particular issue or can also be used to identify trends (B. Pang, Lee, \& Vaithyanathan, 2002). Public sentiments 
regarding a matter may be identified through sentiment analysis. Therefore, twitter sentiment analysis is a cheap and fast way to analyze public opinion.

Sentiment analysis-based research and applications develop rapidly because of its benefit. By conducting sentiment analysis, texts were grouped into positive, negative, or neutral. In this study, an overview of the content contained in each tweet was provided through sentiment analysis. Therefore, the information in the community with all its pros and cons toward the 2019 presidential election was generated. Such an analysis, specifically that uses social network analysis (SNA) method, is capable of mapping out the crucial topics that the public is talking about and predicting the direction of the presidential election. SNA is a method to map, measure, and analyze relationships between individuals, groups, or organizations socially (Blanchet \& James, 2012). This method can provide a visual description of the explored patterns that appear between the candidate figures from the relationship between dots (nodes) and the lines that connect them (DeBrún \& McAuliffe, 2018). This method was used in this study to see the patterns generated from the hashtags used to disseminate particular information as a form of campaign strategy.

\section{Data Collection}

The authors limited the data set by focusing on tweets that can be traced via two specific hashtags, \#2019GantiPresiden and \#Jokowi2Periode, to find a picture of sentiments towards the two pairs of candidates for president and vice-president of the Republic of Indonesia among Twitter users. Such a sentiment picture was obtained by exploring the contents of tweets using content analysis. Tweets with the two hashtags were collected and subsequently analyzed with the help of the MAXQDA version 18.1.1 software. The collected Twitter data were put into data-sets by utilizing the Application Program Interface (API) to make them ready to access. API is a means that allows different computer programs to communicate with each other, including requesting and presenting information from and to each other. This process was done by enabling the software application to retrieve what is called the endpoint from addresses linked to certain types of information on Twitter. Twitter data are different from data shared by most other social platforms in that they reflect information the users choose to share publicly. API is a public platform with which data is selected by users to be processed and shared in various forms. The data generated are then processed using Google Fusion for further visualization and analysis according to the focus of the study (Ashari, Tjoa, \& Riasetiawan, 2016). For the record, this present study upheld psychological research ethics. To maintain data confidentiality, Twitter usernames and their tweets were anonymous. Considering that the data collection strategy relied heavily on the tweets extracting process, the data from this sample were not comprehensive nor representative.

\section{Results}

The data collection process obtained 92,276 tweets containing various hashtags and authors from one week before and one week after each of the four-time presidential and vicepresidential candidate debates held between January and April 2019. Viewed from the tweet posting time, Twitter users posted their tweets during productive hours, which was between 09:00 AM and 12:00 AM (20.4 percent of total tweets) (see Figure 1), followed by those posted on between 12:00 AM and 03:00 PM (17.3 percent) and between 03:00 - 06:00 PM (15.6 percent). In accumulation, these three time-frames dominated the tweets posting timing by $53.3 \%$. Therefore it can be interpreted that many Twitter users use their office hours to express their opinions through tweets containing the two hashtags mentioned above. 


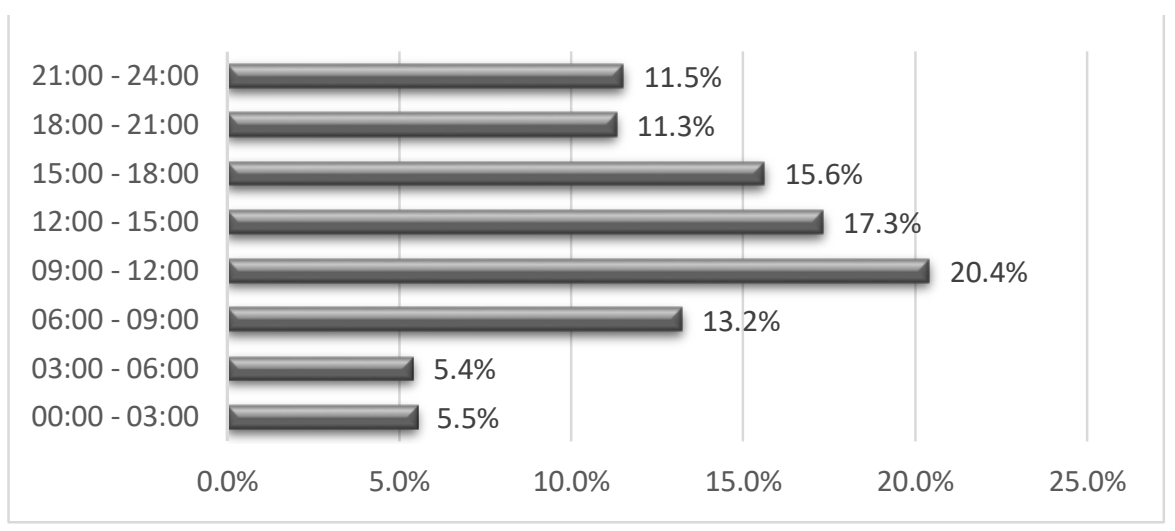

Figure 1. Percentages of tweets by posting time

Despite the different times of posting, all tweets contained either the \#Jokowi2Periode or \#2019GantiPresiden hashtag. Figure 2 shows the five most frequently used hashtags, which overall accounted for 60.4 percent of all tweets.

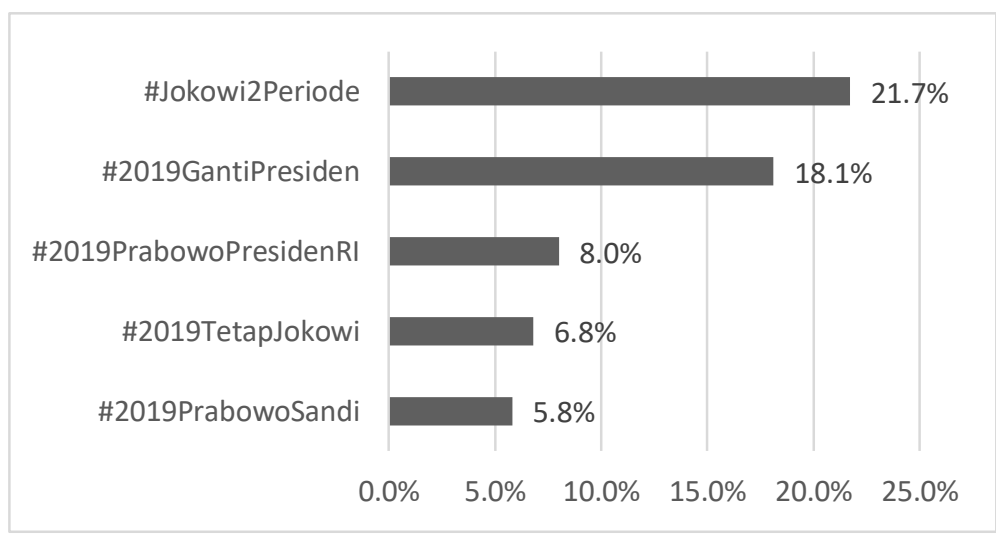

Figure 2. Five most frequently used hashtags

Figure 3 shows words mentioned in at least 2,000 tweets were also found in the form of a word cloud. As shown in Figure 2 and Figure 3 , the two hashtags were still very dominant compared to other hashtags or words. Nevertheless, all the hashtags and words in the word clouds, either dominant or not, were still in the election context. Therefore, tweets that used \#Jokowi2Periode and \#2019GantiPresiden hashtags contained particular sentiments.

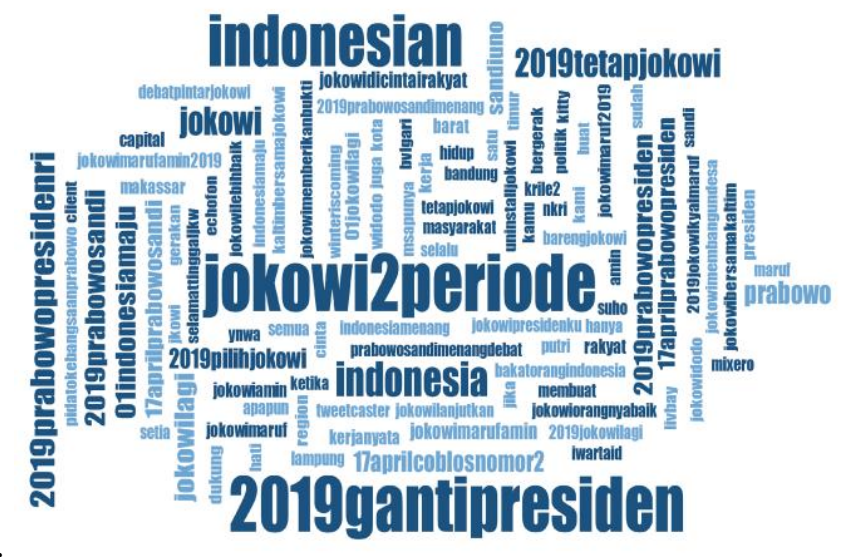

Figure 3. Word cloud 
The authors carried out a sentiment analysis to reveal the sentiments that emerged from each tweet. The results of the sentiment analysis were grouped into three major categories, namely negative sentiments with values ranging from .01 to .35 , neutral sentiments with values ranging from .36 to .64 , and positive sentiments with values ranging from .65 to 1.00 . Other values were classified as out of range. The comparison of sentiment percentages based on the two prominent hashtags is shown in Figure 4.

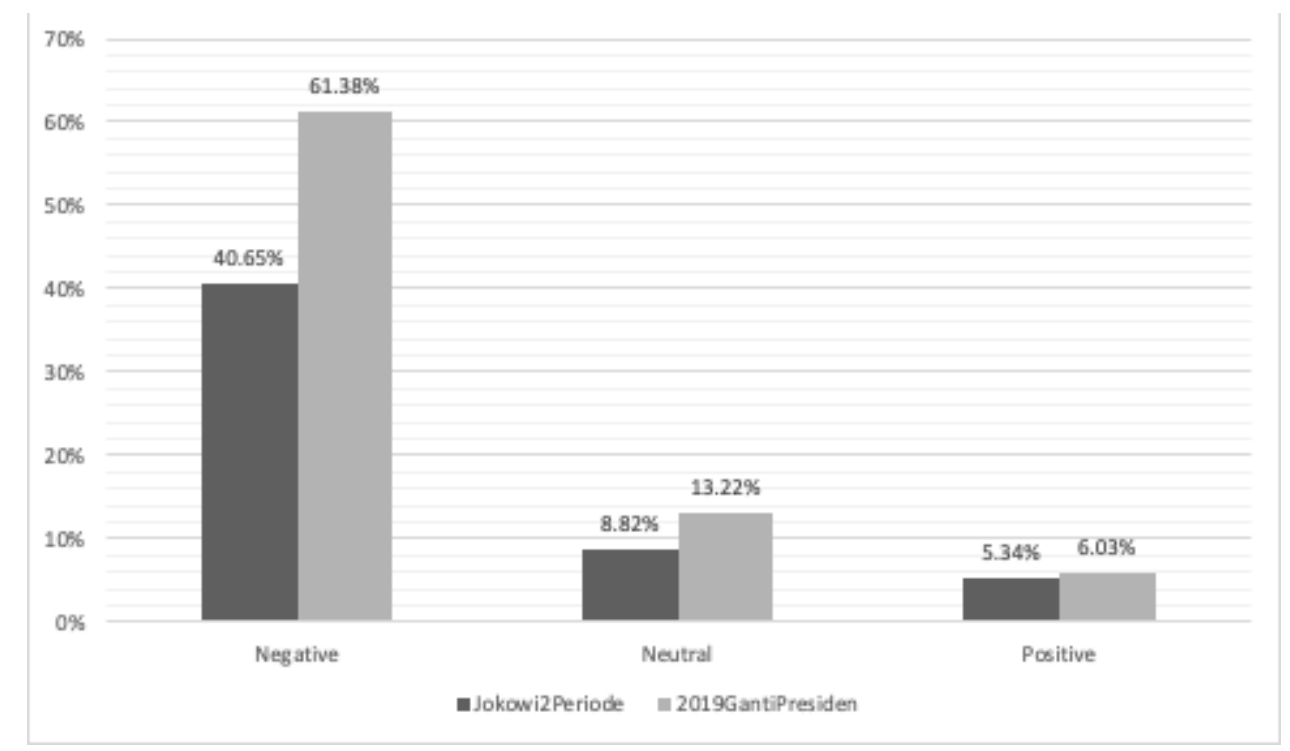

Figure 4. Percentages of posted tweets comparison based on types of sentiments and hashtags

As seen in Figure 4, the percentage of tweets containing negative sentiment with the \#2019GantiPresiden hashtag was 61.38 percent, which was higher than that of the \#Jokowi2Periode hashtag (40.65 percent). Besides, these percentages were the largest in each of the two hashtags. In other words, tweets with those two hashtags were dominated by words containing negative sentiments, especially those aimed at the opposing party. On the contrary, only, respectively, 5 to 6 percent tweets with the two hashtags contained positive sentiments. This almost 10-fold difference indicated that Twitter users tended to make efforts to bring down the opposing candidate to get more support from prospective voters rather than focusing on the positive side of the candidate they endorsed.

All sentiments obtained from tweets containing each hashtag then formed some patterns. It seemed that the formed patterns were used by the two presidential candidate pairs to design campaign strategies that were very different from each other. The \#2019GantiPresiden hashtag was affiliated with \#2019PrabowoSandi hashtag, which then formed a centralized pattern. Unlike the \#2019GantiPresiden hashtag, the hashtags that were affiliated with \# Jokowi2Periode hashtag tended to form a pattern which was small and decentralized, spread in various areas (see Figure 5).

Another unique finding was that the \#Jokowi2Periode hashtag was between two hashtags affiliated with the \#2019GantiPresiden hashtag. These dots (nodes), if focused, will show lines that also went into the two \#2019GantiPresiden networks. This finding indicates that the networks were collections of tweets that contained both hashtags or linked to both hashtags either directly and indirectly. 


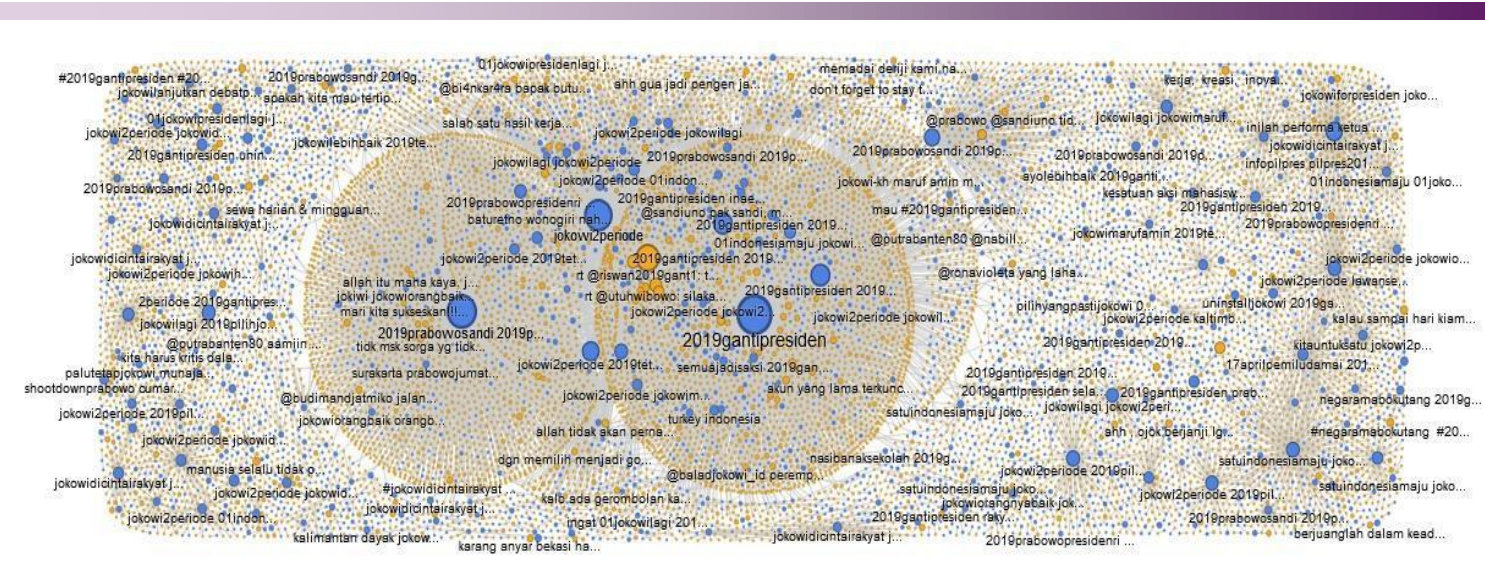

Figure 5. Hashtag distribution pattern

\section{Discussion}

In the 2019 Presidential Election, Indonesia repeated the success of political campaigns through Twitter, an online media, as was done in the United States on the 2008 and 2012 Presidential Elections (Johnson, 2012). Twitter was used as a medium for political marketing through hashtag posts from supporters of both presidential candidates. Two hashtags stood out and became trending topics on Twitter; they were \#2019GantiPresiden and \#Jokowi2Periode (Aji, 2018; Hakim, 2018). The distribution of the two candidate strongholds' hashtags formed the hashtag distribution patterns found in this study. In addition to \#Jokowi2Periode and \#2019GantiPresiden hashtags, the two candidate strongholds also produced several other different hashtags, which then formed inter-affiliated networks (see Figure 2).

Some hashtags that were affiliated with the \#2019GantiPresiden hashtag formed a large and centralized pattern, while hashtags that were affiliated with the \#Jokowi2Periode hashtag formed smaller networks spread in various areas. These findings indicate differences in the campaign strategies chosen by each candidate where candidate Prabowo Subianto through \#2019GantiPresiden hashtag launched a centralized political maneuver under one command of a campaign leader, thus forming an extensive network. A cues-filtered-in theory that is the Social Identity Model of Individual Effects (SIDE) (Lea \& Spears, 1992) explained the centralized pattern of \#2019GantiPresiden hashtag. This theory stated communicators use text-based communication without visual information will drive to communication-based on visual anonymity. In such conditions, communicators become deindividualized and then will identify with a social group that appears, and may behave following this social group. The visible impact of this was the strong in group favoritism at the \#2019GantiPresiden hashtag as a group.

In every tweet post, both strongholds' supporters included either \#Jokowi2Periode or \#2019GantiPresiden hashtag so that they became trending topics on Twitter. Once the two hashtags were included in the trending topic list, the mindset of prospective voters changed. The changes in the mindset of prospective voters were indicated by their tendency to easily conclude the contents and hashtags posted by each candidate stronghold. Lea \& Spears (1992) explained through the Social Identity Model of the Deindividuation Effect (SIDE) theory that in social media where individuals do not have access to non-verbal cues will result in individuals experiencing deindividuation. Such a condition makes individuals who are continuously exposed to certain information become familiar with that information. If that information has things in common with them, then in group favoritism condition results, and they will support it. Conversely, if that information is different from them, out group derogation condition results and causes them to become increasingly against it. Individuals will thus identify themselves with the group's identity because of the similarities with their own identities as appear in the trending topics on Twitter. 
Changes in the mindset of prospective voters occurred because they processed information heuristically and then preferred to follow consensus arguments and opinions (Chaiken \& Ledgerwood, 2012; Davis \& Tuttle, 2013; Maio, Haddock, \& Verplanken, 2019; Sundar, 2008). The heuristic-systematic model suggests that consumers of information on the internet tend to overcome information overload using strategies that can minimize cognitive efforts by using cognitive heuristics. A cognitive heuristic tends to ignore content to make decisions faster, without using complex methods, and thus can reduce cognitive burdens during message processing (Metzger \& Flanagin, 2013). Such a process makes adaptive choices that need minimum time and knowledge to create (Gigerenzer \& Todd, 1999), although some view that information that is processed heuristically will likely lead to biased information processing (Kahneman, Slovic, Slovic, \& Tversky, 1982).

Unlike his rival, candidate Joko Widodo tended to separately produce hashtags that were affiliated with the \#Jokowi2Periode hashtag from various supporters, spread to various areas (decentralization). A centralization implies that the power rests on the campaign leader (Poguntke \& Webb, 2005). The candidate usually builds a campaign organization and focuses on some communication techniques in their campaign (Brox \& Shaw, 2006). In contrast, decentralization implies that the power is not centered on one figure but distributed to various individuals or organization members (Pennings \& Hazan, 2001). Through the decentralization process in their campaign, the voters will usually vote based on their evaluation of the candidate's image (Balmas, Rahat, Sheafer, \& Shenhav, 2014).

This phenomenon of decentralization can be explained from cues-filtered-out theories, which generally try to see individuals as active actors in directing the communication and relationship process according to their goals, desires, and needs, including when challenged with obstacles or limitations because they can also adapt. One of the cues-filtered-out theories is Walther's hyper-personal theory. Walther (2011) states that CMC can assist in the development of interpersonal relationships that can even go beyond face-to-face communication. From the sender's side, the sender has the freedom to construct his/her selfpresentation as he/she wishes because of its asynchronous nature. Many studies state that $\mathrm{CMC}$ has a striking difference from face to face communication in the relationship that gives rise to nonverbal elements that are not found in CMC. When the signs are not in the form of a message, the intention conveyed will not occur. Culnan \& Markus (1987) named it as a cues-filtered-out perspective. Without the non-verbal signs, the sender does not easily change the feeling of the message, the feeling of communication individually, or shows dominant charisma. There is also a loss of information about a person's background, such as personality, style, and intention.

Positive campaign messages on Twitter will usually get a quick response in the form of pleasant expressions with the use of positive words or emoticons that indicate like or approval. Conversely, negative feedback can be demonstrated through slow responses and the use of negative words or emoticons that indicate dislike or disapproval (Novak, Smailovic, Sluban, \& Mozetic, 2015). The leaders in the \#Jokowi2Periode campaign used an interesting self-presentation strategy of constructing attractive impressions and giving quick feedback in responding to tweets. The supporters and the leaders alike have the freedom to build strategies to attract the masses rather than setting some strategy that is prototypically constructed. Such strategy became interesting when the level of people's political participation in electing the President in 2019 reached 81\%, which was considerably high, implying that people wished to be valued for their individuality.

The two hashtags \#Jokowi2Periode and \#2019GantiPresiden, which became trending in the 2019 political contestation in Indonesia, were dominated by negative content aimed to attack the opponent. Both candidate strongholds mutually divulged the weaknesses and culpability of the opponent. Negative information revealed in a campaign can be an effective strategy because it can mobilize prospective voters to support the campaign maker (Ansolabehere \& Iyengar, 1995). Such negative information is often referred to as negativity 
bias. In persuasive communication in political settings, a political candidate is perceived as having ideal leader characteristics. Information about negative traits attached to a candidate makes prospective voters have a sense of information paradox that leads them to change their scheme about the candidate, from initially neutral or positive to negative. Such a change in scheme occurs due to paradox to the expectations they originally held (Coovert \& Reeder, 1990; Skowronski \& Carlston, 1989).

Negative hashtag posts could also be an effect of toxic online disinhibition, a term coined by Suler $(2004, \underline{2005})$. In a toxic online disinhibition condition, individuals can do things they would never do in face-to-face communication, such as expressing anger, criticizing with harsh language, even threatening other individuals. This condition can happen because of the possible anonymity so that someone's identity in online media tends to be unknown except by detecting the IP address used in accessing the internet. Besides, in textdriven interactions like what happens on Twitter, individuals cannot see physical conditions, facial expressions, and physiological responses of one another (invisibility). Posted text messages generally get delayed responses from other parties (a synchronicity), and thus it seems safer to escape after posting something emotional, personal, or hostile.

This hashtag war had heated up on Twitter's timeline since before the presidential election process took place until the time of voting. In the rhetoric study, the use of hashtags as symbols is one of the efforts made by each candidate's stronghold to influence the prospective voters' decision. Hashtag posts on Twitter as a means to influence the mindset of prospective voters in Indonesia peaked during productive hours, between 09.00 and 12.00 AM. This finding is different from what happens in some western countries, such as in Europe and America. In Europe and America, Twitter usage reaches the highest levels during rest hours, which around 19.00 to 23.00 (Adnan \& Longley, 2013; Adnan, Longley, \& Khan, 2014), and more specifically at around 21:00 for tweets with political contents (Wang, Can, Kazemzadeh, Bar, \& Narayanan, 2012). The high use of Twitter during productive hours by many Twitter users in Indonesia may indicate that they are utilizing workplace facilities such as wireless broadband with high internet connection speeds (Hikmayanti \& Suhada, 2012; Rambung, Sembiring, Surjati, \& Mandagi, 2017; Sadikin, Sari, \& Jumanta, 2019). The high internet connection speeds allow them to share and receive information more quickly and get more satisfaction in social media (Hsiao-HuiWang \& CHen, 2011).

The limitations in this study are a) the process of data retrieval, b) the demographic characteristics, and b) the deep explanation about its context. Data were obtained in a limited period, a week before and after the official presidential debate, since the application we used has a time limitation. Also, demographic characteristics cannot be obtained from Twitter. Moreover, this study has not stated much about political psychology.

Based on the limitations of this study, further research may use an application that allows users to access the data independently. The demographic characteristics of prospective voters may provide an overview of the likely amount of support for each pair of candidates in various electoral districts. Political psychology perspective may be employed to understand data comprehensively. As for theoretical development purposes, future researchers may explore research results using a discourse analysis approach to analyze Twitter contents. For practices, this study suggested policymakers and related parties use Twitter as a social media to disseminate information or launch campaigns through certain hashtags.

\section{Conclusion}

This study found that the hashtag \# 2019GantiPresiden and \# Jokowi2Periode created networks that represent the campaign strategies. Using a theoretical framework, \#2019GantiPresiden works centralized, which influenced by the media used (based on cuesfiltered-in theory). On the other side, \#Jokowi2Periode shows spreading patterns (decentralized) to various areas, showing it depends on the actor's presentation, which fulfills 
the sign-filtered theory and hyper-personal theory. Thus, Twitter was made as a media that builds rhetoric that can be adapted to specific preference models to be able to attract supporters during the 2019 Presidential Election period in Indonesia.

\section{Acknowledgment}

The authors are thankful to the Faculty of Psychology Universitas Gadjah Mada, who funded this study. We certify that the authors have no affiliations with or involvement in any organization in the subject matter or materials discussed in this manuscript.

\section{References}

Adnan, M., \& Longley, P. (2013). Analysis of Twitter usage in London, Paris, and New York City. AGILE 2013, Leuven, Belgium, 14-17 May 2013.

Adnan, M., Longley, P. A., \& Khan, S. M. (2014). Social dynamics of Twitter usage in London, Paris, and New York City. First Monday, 19(5). https://doi.org/10.5210/fm.v19i5.4820

Aji, M. R. (2018). Politikus PKS Mardani Ali Sera bikin Gerakan \#2019GantiPresiden [Politician from PKS Mardani Ali Sera created \#2019Ganti Presiden movement]. Teтро. https://nasional.tempo.co/read/1076303/politikus-pks-mardani-ali-sera-bikingerakan-2019gantipresiden/full\&view=ok

Ansolabehere, S., \& Iyengar, S. (1995). Going negative: How attack ads shrink and polarize the electorate. New York: Free Press.

Ashari, A., Tjoa, A. M., \& Riasetiawan, M. (2016). Cloud-based processing for data science visualization. International Journal of Advanced Computer Science and Applications, $7(2), 449-454$.

Atkins, J., Finlayson, A., J, M., \& Turnbull, N. (2014). Rhetoric in British politics and society. Hampshire: Springer.

Balmas, M., Rahat, G., Sheafer, T., \& Shenhav, S. R. (2014). Two routes to personalized politics: Centralized and decentralized personalization. Party Politics, 20(1), 37-51. https://doi.org/10.1177/1354068811436037

Blanchet, K., \& James, P. (2012). How to do (or not to do)...a social network analysis in health systems research. Health Policy and Planning, 27(5), 438-446. https://doi.org/10.1093/heapol/czr055

Brox, B. J., \& Shaw, D. R. (2006). Political parties, American campaigns, and effects on outcomes. In R. S. Katz \& W. J. Crotty (Ed.), Handbook of party politics (pp. 146159). SAGE Publications Ltd.

Burke, K. (1969). A rhetoric of motives. Los Angeles: University of California Press.

Chaiken, S., \& Ledgerwood, A. (2012). A theory of heuristic and systematic information processing. In P. A. M. Van lange, A. W. Kruglanski, \& E. T. Higgins (Ed.), Handbook of theories of social psychology (Vol. 1, pp. 246-266). SAGE Publications Ltd.

Coovert, M. D., \& Reeder, G. D. (1990). Negativity effects in impression formation: The role of unit formation and schematic expectations. Journal of Experimental Social Psychology, 26(1), 49-62. https://doi.org/10.1016/0022-1031(90)90061-p

Culnan, M. J., \& Markus, M. L. (1987). Information technologies. In F M. Jablin, L. L. Putnam, K. H. Roberts, \& L. W. Porter (Eds.), Handbook of organizational communication: An interdisciplinary perspective (pp. 420-443). Newbury Park: CA Sage. 
Curini, L., \& Martelli, P. (2010). Ideological proximity and valence competition. Negative campaigning through allegation of corruption in the Italian legislative arena from 1946 to 1994. Electoral Studies, 29(4), 636-647. https://doi.org/10.1016/j.electstud.2010.06.004

Davis, J. M., \& Tuttle, B. M. (2013). A heuristic-systematic model of end-user information processing when encountering IS exceptions. Information \& Management, 50(2-3), 125-133. https://doi.org/10.1016/j.im.2012.09.004

De Brún, A., \& McAuliffe, E. (2018). Social network analysis as a methodological approach to explore health systems: A case study exploring support among senior managers/executives in a hospital network. International Journal of Environmental Research and Public Health, 15(3), 511-521. https://doi.org/10.3390/ijerph15030511

Enli, G. (2017). Twitter as arena for the authentic outsider: Exploring the social media campaigns of Trump and Clinton in the 2016 US presidential election. European Journal of Communication, 32(1), 50-61. https://doi.org/10.1177/0267323116682802

Esser, F., \& Strömbäck, J. (2012). Comparing Election Campaign Communication. In F. Esser, \& T. Hanisch (eds.), The handbook of comparative communication research (pp. 289-307). New York: Routledge.

Franz, M. M., Freedman, P., Goldstein, K., \& Ridout, T. N. (2008). Understanding the effect of political advertising on voter turnout: A response to Krasno and Green. The Journal of Politics, 70(1), 262-268. https://doi.org/10.1017/S0022381607080188

Fridkin, K. L., \& Kenney, P. (2011). Variability in citizens' reactions to different types of negative campaigns. American Journal of Political Science, 55(2), 307-325. https://doi.org/10.1111/j.1540-5907.2010.00494.x

Gigerenzer, G., \& Todd, P. M. (1999). Simple heuristics that make us smart. Oxford University Press, USA.

Hakim, R. N. (2018). Menurut PKS, Tagar “\#2019GantiPresiden” Tak Langgar Hukum [According to PKS, hashtag \#2019GantiPResiden did not violate the law]. Kompas. https://nasional.kompas.com/read/2018/04/04/19172781/menurut-pks-tagar2019gantipresiden-tak-langgar-hukum

Herrick, J. A. (2017). The history and theory of rhetoric: An introduction. Routledge.

Hikmayanti, H., \& Suhada, M. E. (2012). Implementasi Metro Area Network dengan pendekatan Wireless Broadband dan Gigabit Ethernet Passive Optical Network (GEPON) [Implementation of Metro Area Network using Wireless Broadband and Gigabit Ethernet Passive Optical Network (GEPON) approach]. Syntax: Jurnal Informatika, 1(01). https://doi.org/10.35706/syji.v1i01.278

Housley, W., Webb, H., Williams, M., Procter, R., Edwards, A., Jirotka, M., ... Williams, M. (2018). Interaction and transformation on social media: The case of Twitter campaigns. Social Media+ Society, 4(1), 1-12. https://doi.org/10.1177/2056305117750721

Hsiao-Hui Wang, E., \& CHen, C.-Y. (2011). System quality, user satisfaction, and perceived net benefits of mobile broadband services. Paper Presented at 8th ITS Asia-Pacific Regional Conference, Taipei 2011: Convergence in the Digital Age. International Telecommunications Society (ITS). https://ideas.repec.org/p/zbw/itsp11/52334.html

Jahanbakhsh, K., King, V., \& Shoja, G. C. (2012). Predicting missing contacts in mobile social networks. Pervasive and Mobile Computing, 8(5), 698-716. https://doi.org/10.1016/j.pmcj.2012.07.007

Johnson, J. (2012). Twitter bites and Romney: Examining the rhetorical situation of the 2012 presidential election in 140 characters. Journal of Contemporary Rhetoric, 2(3/4), 5464. 
Kahneman, D., Slovic, S. ., Slovic, P., \& Tversky, A. (1982). Judgment under uncertainty: Heuristics and biases. New York: Cambridge University Press.

Kennedy, G. (1991). Aristotle, on Rhetoric. A theory of civic discourse. New York and Oxford: Oxford University Press.

Khoja-Moolji, S. (2015). Becoming an "intimate publics": Exploring the affective intensities of hashtag feminism. Feminist Media Studies, 15(2), 347-350. https://doi.org/10.1080/14680777.2015.1008747

Kuwado, F. J. (2018). Besok, Massa Pendukung \#2019GantiPresiden Datang ke Seberang Istana [Tomorrow, the supporters of \#2019GantiPresiden are coming to the National Palace]. Kompas. https://nasional.kompas.com/read/2018/05/05/19074811/besokmassa-pendukung-2019gantipresiden-datang-ke-seberang-istana

Lachlan, K. A., Westerman, D. K., \& Spence, P. R. (2010). Disaster news and subsequent information seeking: Exploring the role of spatial presence and perceptual realism. Electronic News, 4(4), 203-217. https://doi.org/10.1177/1931243110387092

Lea, M., \& Spears, R. (1992). Paralanguage and social perception in computer-mediated communication. Journal of Organizational Computing and Electronic Commerce, 2(34), 321-341. https://doi.org/10.1080/10919399209540190.

Liang, Y. J., \& Walther, J. B. (2015). Computer-Mediated Communication. International Encyclopedia of the Social \& Behavioral Sciences: Second Edition, 504-509. https://doi.org/10.1016/B978-0-08-097086-8.95090-6

Listiyani, D. (2019). 1,3 juta tweet meriahkan debat perdana Pilpres 2019 [1,3 million tweets enlivened the first debate of president election 2019]. INews Portal. https://www.inews.id/techno/internet/1-3-juta-tweet-meriahkan-debat-perdanapilpres-2019

Maio, G. R., Haddock, G., \& Verplanken, B. (2019). The psychology of attitudes and attitude Change (Third edition). SAGE Publications Ltd.

Makki, S. (2018). KPU: Jumlah pemilih tetap Pemilu 2019 capai 192 juta [the number of fixed voters of the 2019 election reached 192 million]. CNN Indonesia. https://www.cnnindonesia.com/nasional/20181215171713-32-353929/kpu-jumlahpemilih-tetap-pemilu-2019-capai-192-juta

Metzger, M. J., \& Flanagin, A. J. (2013). Credibility and trust of information in online environments: The use of cognitive heuristics. Journal of Pragmatics, 59, 210-220. https://doi.org/10.1016/j.pragma.2013.07.012

Naren, D. (2018). Sekjen PKS Mardani Ali Sera canangkan Gerakan 2019 Ganti Presiden: Sah, legal dan konstitusional [Secretary General PKS Mardani Ali Sera is planning the "2019 Ganti Presiden" movement: legitimate, legal and constitutional]. TribunWow. https://wow.tribunnews.com/2018/03/28/sekjen-pks-mardani-ali-sera-canangkangerakan-2019-ganti-presiden-sah-legal-dankonstitusional?page $=$ all\&_ga $=2.107107138 .159931190 .1523411763-$ 1426122679.1523411763

Novak, P. K., Smailovic, J., Sluban, B., \& Mozetic, I. (2015). Sentiment of Emojis. PLoS ONE, 10(12). https://doi.org/10.1371/journal.pone.0144296.

Pang, B., Lee, L., \& Vaithyanathan, S. (2002). Thumbs up? Sentiment classification using Machine Learning Techniques. Conference on Empirical Methods in Natural Language Processing (EMLP) (pp. 79-86). https://doi.org/10.1016/0096-6347(45)90048-2

Pang, N., \& Law, P. W. (2017). Retweeting\# WorldEnvironmentDay: A study of content features and visual rhetoric in an environmental movement. Computers in Human Behavior, 69, 54-61. https://doi.org/10.1016/j.chb.2016.12.003

Papacharissi, Z. (2002). The virtual sphere. New Media \& Society, 4(1), 9-27. 
https://doi.org/10.1177/14614440222226244

Pennings, P., \& Hazan, R. Y. (2001). Democratizing candidate selection: Causes and consequences. Party Politics, 7(3), 267-275. https://doi.org/10.1177/1354068801007003001

Poguntke, T., \& Webb, P. (2005). The presidentialization of politics in democratic societies: A framework for analysis. In T. Poguntke \& P. Webb (Ed.). The presidentialization of politics: A comparative study of modern democracies (pp. 1-25). Oxford University Press.

Rambung, R. A., Sembiring, R. J., Surjati, I., \& Mandagi, A. (2017). Implementation of broadband technology Infrastructure using Techno-Economic Analysis (A Case at the Government of West Java Province). Teknik Dan Ilmu Komputer, 6(22).

Ridout, T. N., \& Smith, G. R. (2008). Free advertising: How the media amplify campaign messages. Political Research Quarterly, 61(4), 598-608. https://doi.org/10.1177\%2F1065912908314202

Sadikin, N., Sari, M., \& Jumanta, J. (2019). Implementasi jaringan nirkabel BWA (Broadband Wireless Access) menggunakan Wimax [Implementation of BWA (Broadband Wireless Access) wireless network using Wimax]. KILAT, 8(2), 141-150. https://doi.org/10.33322/kilat.v8i2.408

Skowronski, J. J., \& Carlston, D. E. (1989). Negativity and extremity biases in impression formation: A review of explanations. Psychological Bulletin, 105(1), 131. https://doi.org/10.1037/0033-2909.105.1.131

Suler, J. (2004). The online disinhibition effect. Cyberpsychology and Behavior, 7(3), 321326. https://doi.org/10.1089/1094931041291295

Suler, J. (2005). The online disinhibition effect. International Journal of Applied Psychoanalytic Studies, 2(2), 184-188. https://doi.org/10.1002/aps.42

Sundar, S. S. (2008). The MAIN model: A heuristic approach to understanding technology effects on credibility. In M. J. Metzger \& A. J. Flanagin (Ed.). Digital media, youth, and credibility (pp. 73-100). The MIT Press. https://doi.org/10.1162/dmal.9780262562324.073

Triyoga, H., \& Nugraha, B. (2018). Presiden PKS Sebut Inisiator Gerakan \#2019GantiPresiden [The Presiden PKS pointed the initiator of \#2019GantiPresiden Movement]. Viva. https://www.viva.co.id/berita/politik/1024652-presiden-pks-sebutinisiator-gerakan-2019gantipresiden

Vlatković, S. (2018). New communication forms and political framing: Twitter in Donald Trump's presidential campaign. AM Časopis Za Studije Umetnosti i Medija, 16, 123134. https://doi.org/10.25038/am.v0i16.259

Walther, J. B. (2011). Theories of computer-mediated communication and interpersonal relations. The Handbook of Interpersonal Communication, 4, 443-479.

Wang, H., Can, D., Kazemzadeh, A., Bar, F., \& Narayanan, S. (2012). A system for realtime Twitter sentiment analysis of 2012 U.S. presidential election cycle. Paper Presented at The 50th Annual Meeting of the Association for Computational Linguistics, Jeju, Republic of Korea, 8-14 July 2012.

Weller, K., Bruns, A., Burgess, J., Mahrt, M., \& Puschmann, C. (2014). Twitter and society. New York: Peter Lang.

Zappavigna, M. (2011). Ambient affiliation: A linguistic perspective on Twitter. New Media and Society, 13(5), 788-806. https://doi.org/10.1177/1461444810385097 